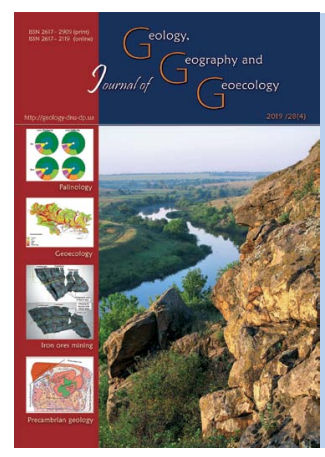

Journal of Geology,

\title{
Prospects for introducing inclusive rehabilitation and social tourism in Ukraine
}

\author{
Natalia V. Bielousova ${ }^{1}$, Olha A. Lyubitseva² \\ ${ }^{1}$ National Aviation University, Kyiv, Ukraine, belousova-69@ukr.net \\ ${ }^{2}$ Kiev National University named after Taras Shevchenko, Geography Faculty. Department of Country Studies and \\ Tourism,Kyiv,Ukraine,loa13@ukr.net
}

Received: 27.03.2019

Received in revised form: 06.09.2019

Accepted: 16.11.2019

\begin{abstract}
The article highlights the theoretical and methodological foundations of inclusive tourism development; substantiates theoretical aspects of the origin and use of the new concept of "inclusive rehabilitation and social tourism"; analyzes the modern world and Ukrainian experience in the development and implementation of inclusive tourism in the tourism sector of Ukraine. The article presents a study of the evolution and future
\end{abstract} introduction of inclusive tourism in the rehabilitation system of Ukraine, taking into account the peculiarities of the regulatory framework, political and economic problems in the country, and, as a result, the social standard of living of Ukraine. We provide a classification of groups of inclusive tourists according to the types of inclusion and the possibilities of providing rehabilitation services: social group (Chernobyl veterans, pensioners, pregnant women, large families, and others); the group people with disabilities (various groups of disabilities and nosologies), people with "war syndrome" (Afghan War veterans, military from zones of the ATO, displaced people, people with psychological trauma, children of war, war veterans, and others). The priority directions of rehabilitation care professionals were determined depending on the inclusive profile and nosology: therapeutic and recreational, cultural-cognitive, family-youth, professional-labour, non-Olympic physical culture and sports. The components for each segment of rehabilitation and social services for people with inclusion due to tourist activities are identified. A conceptually new theoretical and methodological block model of an"accessible" inclusive environment for rehabilitation of people of various inclusive groups and nosologies is presented. The connection between the main elements of this model of inclusive rehabilitation tourism is established. In order to fully understand the level of the need for the introduction of inclusive tourism in Ukrainian society, not only is a thorough scientific and methodological base needed, but also practical testing of the results.

Keywords: inclusive tourism, people with need for inclusion, small-scale groups, inclusive tourists, rehabilitants

\section{Перспективи впровадження інклюзивного реабілітаційно-соціального туризму в Україні}

\author{
Н.В. Бєлоусова ${ }^{1}$, О.О. Любіцева ${ }^{2}$ \\ ${ }^{1}$ Національний авіаційний університет, Київ, Украӥна, belousova-69@ukr.net \\ ${ }^{2}$ Киівський національний університет імені Тараса Шевченка, Київ, Україна, loa13@ukr.net
}

\begin{abstract}
Анотація. В статті висвітлені теоретико-методологічні основи розвитку інклюзивного туризму; обгрунтовані теоретичні аспекти походження та використання нового поняття «інклюзивний реабілітаційно-соціальний туризм»; проаналізований сучасний світовий та український досвід розвитку та впровадження інклюзивного туризму в туристичну сферу України. Проведено дослідження еволюції і перспективного впровадження інклюзивного туризму в реабілітаційну систему України, враховуючи особливості нормативно-законодавчої бази, політичних та економічних проблем в країні, i, як наслідок, соціального рівня життя українців. Надана класифікація груп інклюзивних туристів за типами інклюзії та можливостями надання реабілітаційних послуг: соціальна група (чорнобильці, пенсіонери, вагітні жінки, багатодітні сім ї й інші); група людей з інвалідністю (різні групи інвалідності та нозології); люди з «синдромом війни» (афганці, військові зони АТО, переселенці, які зазнали психологічних травм, діти війни, ветерани війни та інші). Визначені пріоритетні напрями професійної допомоги реабілітантам в залежності від інклюзивного профілю та нозології: лікувально-оздоровчий, культурно-пізнавальний, сімейно-молодіжний, професійно-трудовий, не олімпійський фізкультурно-спортивний види. Визначені складові по кожному сегменту реабілітаційно-соціальних послуг для людей з інклюзією завдяки туристичній діяльності. Надана концептуально нова теоретико-методологічна блокова модель «доступного» інклюзивного середовища для реабілітації людей різних
\end{abstract}


інклюзивних груп і нозологій. Встановлений зв язок між основними елементами даної моделі інклюзивного реабілітаційного туризму. Для повного розуміння рівня необхідності впровадження інклюзивного туризму в український соціум необхідна не тільки грунтовна науково-методична база, але й практична апробація результатів.

Ключові слова: інклюзивний туризм, люди з інклюзією, маломобільні групи, інклюзивні туристи, реабілітанти

Formulation of the problem. Modern trends in the development of modern society of every civilized country provoke the creation of comfortable living conditions for all segments of the population. The social level of Ukrainian society still lags behind European and world standards, does not respond sufficiently to the acute needs of low-income groups that are included in the category of people with inclusion. The study of the process of integration into society of individuals with inclusion, and, above all, people with disabilities, the development of principles, mechanisms, key directions, substantiation of practical recommendations of this process and the solution of related problems, is an important and urgent task to Ukrainian society.

Despite the efforts observed in Ukraine, the situation about integration of people with disadvantages into society, it's social activity and professional selfrealization are still low. The situation is complicated by the presence of subjective factors: a weak level of public consciousness, self-stigmatization of people with disabilities, their weak motivational mechanisms, instability of incentives for independent living and social adaptation, as well as the lack of practical assistance in the form of a state rehabilitation programme. In our opinion, the most universal and versatile means for restoring a person's general condition is tourism, as a generally recognized means of rest, recreation, adaptation, cognition of the environment, which contributes to the comprehensive rehabilitation of a person.

The scientific idea of this publication is to show that in Ukraine there is a problem of professional assistance to people with inclusion, especially to people with disabilities, and it can be solved by means of geography and tourism, as interdisciplinary research areas in tourism research.

Analysis of previous research. Since 2006, the problems of inclusion have been considered by both foreign specialists from various fields, as well as researchers from Ukraine and the near abroad. Various foreign scientific schools offer a number of research works that highlight the problems of theoretical substantiation and practical application of methods, techniques, practices related to inclusive tourism, in which tourism acts as an accessible, barrier-free environment that helps in the adaptation of people with disabilities.
A general analysis of the academic literature on the subject of "Tourism" indicates a significant number of theoretical works, among which are the works of V. I. Azar, M. B. Birzhakova, JI.H. Zakharova, V.A. Kvartalnova, N. Kobilyatsky, JI.I. Lubysheva, V.D. Panachev, A.A. Terentyev, and others. However, the above authors do not consider purely inclusive tourism in their works.

Many authors, observe the treatment as social institutions directly related to tourism, associate tourism with sports (the touristic institutions includes sports tourism), social protection (the institution social protection includes rehabilitation tourism) and education (the educational institutions includes children's and youth tourism), considering separately rehabilitation or medical assistance.

In the related fields of science (pedagogy, physical culture, sports, medicine), the directions of educational and health tourism are actively developed, which are reflected in the works of: I.A. Droghi, A.A. Ostapets-Sveshnikova, L. Rubis, S.A. Sergeyeva. Besides, the presence of works on the sociology of management and tourism economics - A.V. Aristova, N.I. Ilina, G.M. Malyshev (Russia) and others.

During the last decade, domestic scientists, in particular, S. Bogdanov, G. Gavryushenko, A. Kolupaeva, N. Naida, N. Sofiy, I. Yarmoshchuk, and others, devoted their works to the study of the problem of attracting persons with special needs to study in educational institutions to their rehabilitation and socialization to social norms.

Since the mid-1990s, the subject of the study of recreational geography has been the study of the geospatial patterns of human behaviour in the process of recreational activity and the placement of recreational objects, which were created primarily to defense the doctoral dissertations Krachila MP, Beydika AA, Lyubitseva $\mathrm{O}$.A., as well as through the publication of fundamental and regional monographic publications.

A significant achievement in tourism research is the works B.C. Preobrazhenskyi, Yu.A. Vedenina, I.V. Zorin, M.A. Ananyev, N.P. Zachinyaeva, N.S. Falkovich, E.A. Kotlyarov and other researchers of the Soviet period. During the last decade, Ukrainian researchers, in particular, S. Bogdanov, G. Gavryushenko, A. Kolupaeva, N. Naida, N. Sofiy, I. Yarmoshchuk, and others, devoted to their work to the study of the problem of attracting persons with special educational 
needs to educational institutions, their rehabilitation and socialization to social norms ( On Approval of the Procedure for the Psychological Rehabilitation of the Participants of the Antiterrorist Operation and the Victims of the Victorious Revolution», 2017). The issue of recreational and tourist services for inclusive tourists has been raised by such investigators as $\mathrm{M}$. P. Krachilo, O. Beydik, O. O. Lyubitseva (Bozhuk, 2009, Malskaya, Khudo, 2007).

The fundamental research on the development and implementation of inclusive tourism in the rehabilitation system of Ukraine, which will be based on a clear application for methodology and mechanisms for the practical use of modern methods of rehabilitation for people with inclusion through tourism services, are at the stage of formation and scientific substantiation in Ukraine.

The purpose. Based on the subject of the article, it is necessary to focus that the purpose of this research is the theoretical substantiation of the concept of "inclusive rehabilitation and social tourism" as an integration direction in geography, which can consolidate all forms, methods and techniques of rehabilitation for people of different inclusive groups with different nosologies and inclusion. In this regard, the main objectives of scientific work on this topic are: the rationale for the introduction of this direction; coverage of forms, methods and approaches to the problem of providing professional assistance to people with inclusion, especially people with disabilities of various forms, using world experience, regulatory framework and the results of research in recent years. Results.Tourism, as a phenomenon of social life and a derivative of social development, owes its appearance to the industrial stage of human development, which was characterized by the accelerated development of productive forces, the intensification of the division of labour and the development of urbanization processes. Accelerated innovative changes associated with scientific and technological progress contributed to the overall socio-economic development of certain countries, raising the standard of living of their people, changing the nature of work, the way and style of life. Under these conditions the social models of human activity were radically transformed. Tourism has become a form of leisure, as part of an inter-sectoral complex of the country which meet the needs of the population in recreation and rehabilitation, as well as a powerful communicative component of the globalization process (Bogdanov, 2002).

Modern tourism is a multifunctional phenomenon that covers many areas of human activity. Against the background of spectral functions of tourism, the most urgent is recreation as a form of human rehabilitation (Ustimenko, Afanasyeva, 2005).

One of the main and most significant features of tourism activities is that, unlike the branches of material production, the tourism industry does not export a product, but an impression (Natsional'na prohrama profesiynoyi reabilitatsiyi ta zaynyatosti osib z obmezhenymy fizychnymy mozhlyvostyamy na 20062010 roky, 2010).

In addition, the tourism sector is associated with the activities of more than 50 industries. Its development contributes to an increase in the level of employment, the level of innovation of the national economy, contributes to the preservation and development of cultural potential, the caring of ecologically safe environment, and the harmonization of relations between various countries and peoples. Tourism is one of the means of implementing the state's foreign policy on the rehabilitation of the population (Proekt «Bezbaryerna Ukrayina», 2016).

According to the UN World Tourism Organization (UNWTO), the contribution of tourism to the global gross domestic product, taking into account the indirect effect, is $10 \%$. The total number of jobs that directly or indirectly relate to the tourism sector is $11 \%$. In 2017 , the share of international tourist arrivals increased by $4.4 \%$ and amounted to 1,184 million tourists (Bielousova, 2018, Zvit Minsotspolityky za 2017, 2018).

The legal base of Ukraine contains the legal documents, regulations and resolutions: the Constitution of Ukraine, the Laws of Ukraine «On Tourism», «On the Nature Reserve Fund of Ukraine», «On the Development of Tourism and Resorts in Ukraine», «On the Protection of Cultural Heritage», Resolution Of the Cabinet of Ministers of Ukraine dated October 7, 2015 No. 821 «Some issues of implementation in 2015-2017 of the State Regional Development Strategy for the period up to 2020», Order of the Cabinet of Ministers of Ukraine dated March 16, 2017 No. $168-\mathrm{r}$ «On approval of the tourism development strategy and resorts for the period until 2026 «and others (Bielousova, 2018).

Considering the current level of development of society in the world and in Ukraine in particular, it is necessary to state the rapid growth of number of people, and if the conversation is about tourism, then gives rise to the category of inclusive tourists.

If tourism for people with inclusion is considered as a type of recreational tourism designed for people with disabilities, then inclusive tourism (fr. Inclusif -which includes, lat. Include -I conclude, I include) is the process of tourism development, which implies 
the availability of tourism for all, in terms of adapting the infrastructure of tourist centers and tourist facilities to the various needs of all people, including people with disabilities, the elderly, their caregivers and family members, people with temporary disabilities, families with small children, pregnant women, children from large families, etc. (Deno, 1970). In the Ukrainian interpretation, the military, who are in the ATO area, Chernobyl victims, temporary migrants from the east of Ukraine, Afghan War veterans etc., are also referred to as inclusive tourists (Bielousova, 2018, Wang, 2009).

Compared with the already known international classifications of people withfor inclusion, Ukraine has its own characteristics, which are dictated by historical events, the features of its development in recent years, and the specifics of internal and external relations. Given this specificity, we propose a classification of groups of people with inclusion who can prospectively undergo rehabilitation in the process of tourism activities: the social group (Chernobyl victims, pensioners, pregnant women, large families and others); the group of people with disabilities (various groups of disabilities, disorders and diseases), people with «war syndrome» (Afghan War veterans, from military zones of the ATO, displaced people, having psychological trauma, children of war, war veterans, and others) (Fig.1).
It is known that the term "inclusive tourism" is currently not final, either in science or in practice. Such a phenomenon is also defined as "tourism for all", "accessible tourism", "tourism for the disabled", "invaturism", "paratourism", "barrier-free tourism", "rehabilitation tourism", "correctional and educational tourism" and others (Bielousova, 2017).

There are several interpretations of the term «inclusive tourism». In the European Union, the tourism segment for people with disabilities is called "accessible tourism" or "tourism for all." At the same time, the essence of this type of social rehabilitation does not change.

In our opinion, the terms "inclusive tourism" and "tourism accessible to all" are synonymous, and the term "adaptive tourism" reflects the target orientation of tourism activities of persons with special needs in tourism and services. This approach allows us to consider «adaptive tourism» as the possibility of using it in the form of tourist travel in the natural environment. But the term "barrier-free tourism" reflects the degree of fitness of objects displaying the potential of tourism infrastructure and is applied, as a rule, to local tourism or sightseeing activities (Statystyka ta analiz malomobil'nykh verstv naselennya, 2018).

Finally, this term was consolidated in 2009 at the 18th session of the UNWTO General Assembly in Astana (Kazakhstan) in the "Declaration on Facilita-

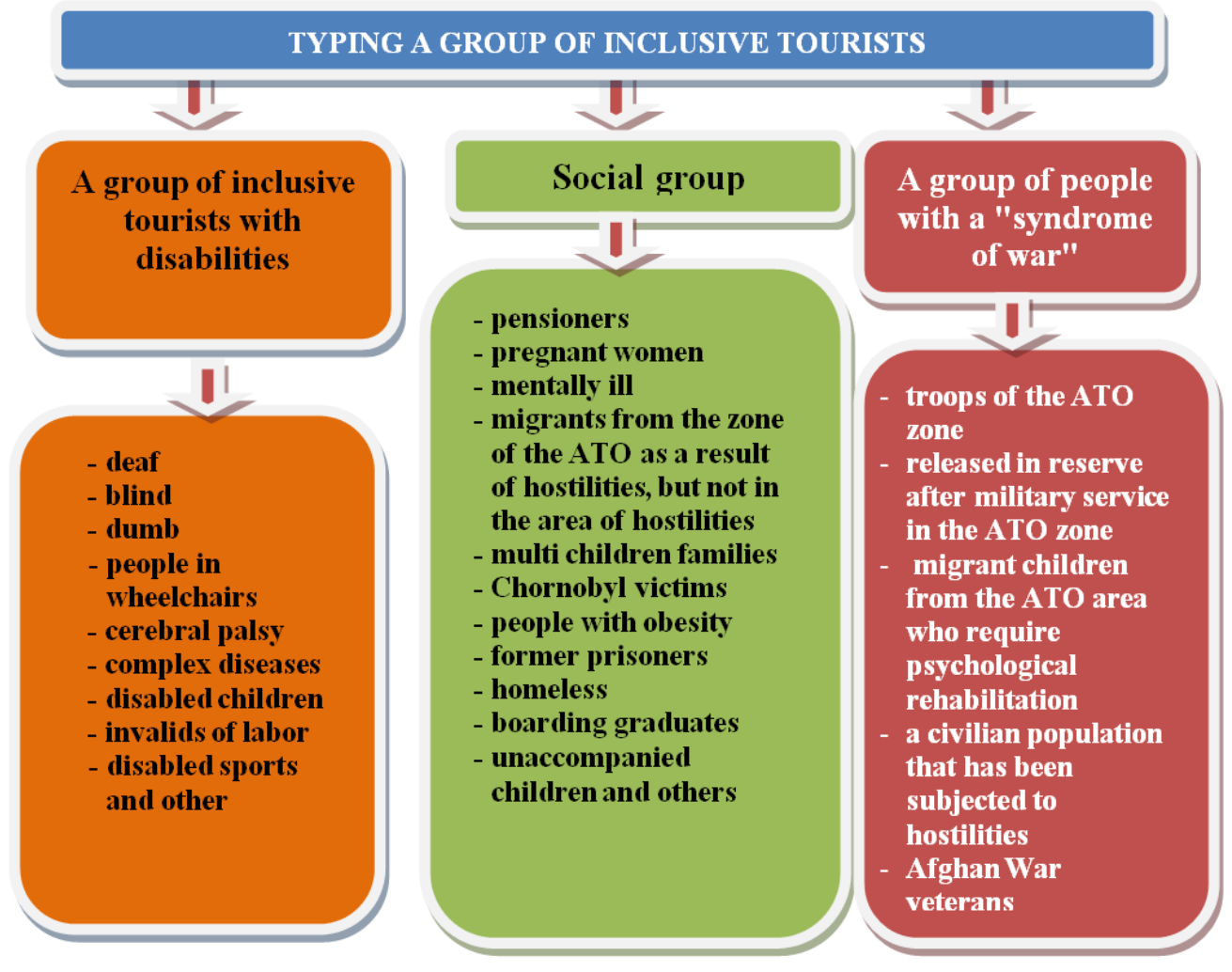

Fig.1. Scheme of classification of groups of inclusive tourists (built by the author) 


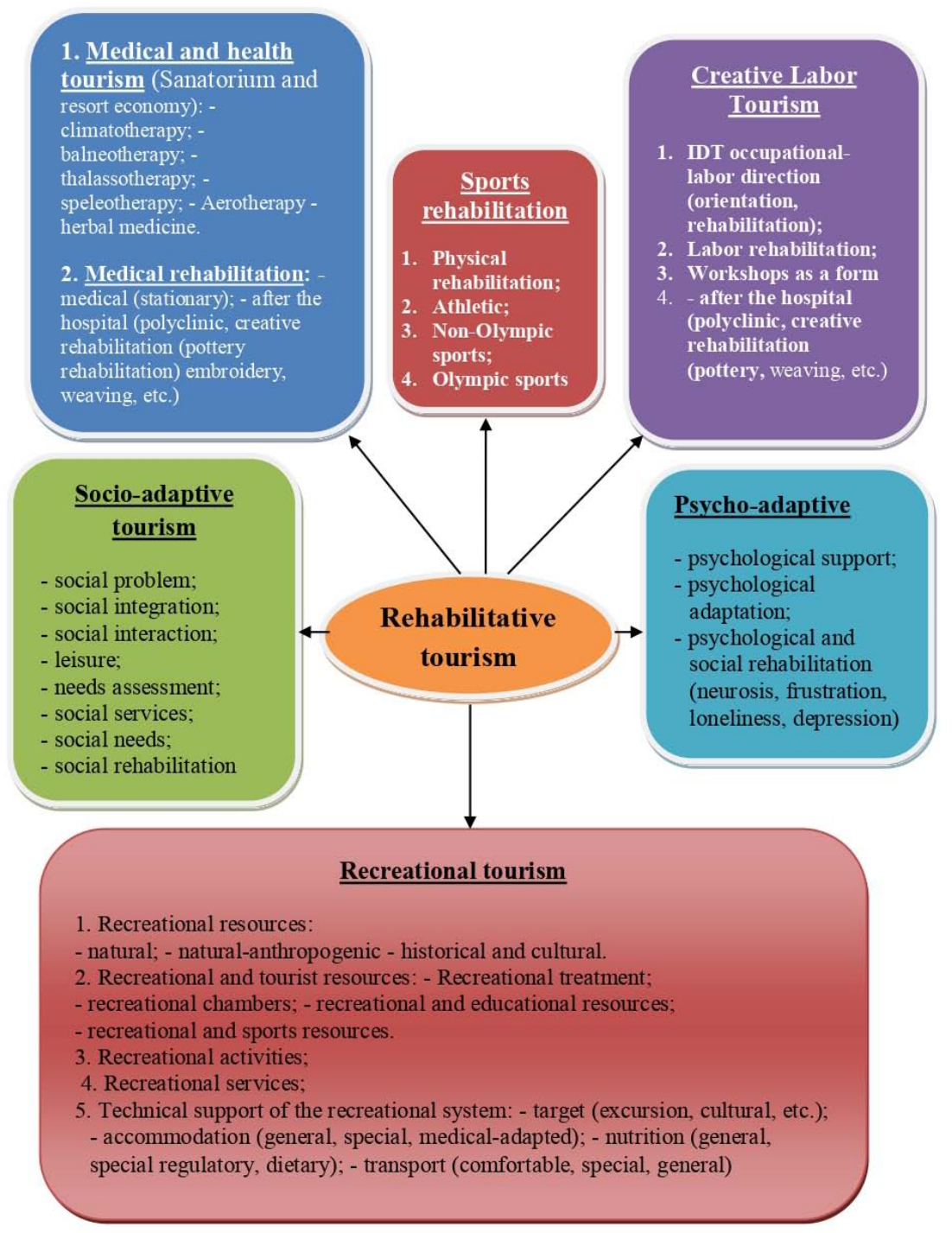

Fig. 2. The main activities of inclusive rehabilitative social tourism

tion of Tourist Travel", in which countries, members of UNWTO, proposed to create tourist facilities and institutions on the territories that would be accessible to people with disabilities, to publish clear and accessible information about existing reception services for them, as well as the problems that they may encounter during their trip (Bielousova, 2017).

Inclusive tourism can also be viewed as a form of tourism which includes the process of cooperation between various participants in the tourism industry. This allows all inclusive categories, especially people with special needs, to be involved in tourism infrastructure using an accessible environment, including mobile, visual, auditory and cognitive components of accessibility, to function independently, as equal minds, with dignity by the universal tourist products, services and environments (Zakon Ukrayiny «Pro kurorty», 2000).

The main activities of inclusive rehabilitative social tourism are medical and recreational, cultural and educational, family and youth, vocational and labour, non-Olympic physical culture and sports types (Fig. 2).

Rehabilitation of people with disabilities is presented to us as a system of medical, psychological, pedagogical, physical, professional, labour, physical culture, sports, social and everyday activities aimed at providing people with assistance in restoring and compensating for impaired or lost body functions, to achieve and maintain social and material independence, labour adaptation and integration into society, as well as providing people with disabilities with technical and other means of rehabilitation, and medical products (paragraph 11, Art. 1 as amended by Law No. 4213-VI (4213-17) of December 22, 2011 p.) (Bozhuk, 2011, Zminy do st.26 Zakonu Ukrayiny «Pro reabilitatsiyu invalidiv v Ukrayini». Ukhvala Verkhovnoyu Radoyu Ukrayiny, 2018).

An individual rehabilitation programme represents optimal types, forms, volumes, periods of re- 
habilitation measures with the definition of the order and place of their implementation, aimed at restoring and compensating for the impaired or lost body functions and abilities of a particular person in order to perform the activities defined in the recommendations of the medical-social expert commission (Lukashevich, Moshak, Shandor,2015).

The development of these areas is preceded by the presence of natural and recreational resources in the form of resort and treatment zones located in the territories for recreational purposes, having natural healing resources and objects of natural, historical and cultural environment and can be used to organize recreational activities - recreation, treatment and tourism, taking into account the services of psychology and psychotherapy and could meet the need for the the following model in tabular form (Table 1).

The increase in the number of inclusive groups amid deterioration of the social standard of living of the Ukrainian people makes one think about creating a mechanism for solving the problem of professional assistance, including the provision of rehabilitation services through the use of travel services. Modern factors of influence on the general condition of the versatile assistance of rehabilitators, determine the tendency towards a new perception of the problem of creating (restoring or using) recreational and tourist zones and uniting key areas of recreation and rehabilitating people of different inclusive groups into a single system of research and services - rehabilitation geography. Such an approach will help to consider tourism through the prism of a complex of rehabili-

Table 1. Model of Social and Physical Rehabilitation of People with Disabilities in Health through Inclusive Tourism

\begin{tabular}{|c|c|c|}
\hline Type of Rehabilitation & Rehabilitation Impacting & Factors \\
\hline \multirow{5}{*}{ Physical rehab } & Recovery & $\begin{array}{l}\text { Driving activity, health-improving technologies of adaptive } \\
\text { physical culture }\end{array}$ \\
\hline & Psycho-emotional influence & $\begin{array}{l}\text { Aesthetic influence of natural and cultural environment, } \\
\text { impression of tourist trips. }\end{array}$ \\
\hline & $\begin{array}{l}\text { Social and communicative } \\
\text { adaptation }\end{array}$ & $\begin{array}{l}\text { Changing the nature and circle of communication, activities in } \\
\text { small groups, changing social role }\end{array}$ \\
\hline & Social-household rehabilitation & $\begin{array}{l}\text { Activities aimed at self-sufficiency, self-care and organization } \\
\text { of everyday life in the conditions of a tourist trip. }\end{array}$ \\
\hline & $\begin{array}{l}\text { Social and environmental } \\
\text { rehabilitation }\end{array}$ & $\begin{array}{l}\text { Mastering the technology of functioning in different } \\
\text { environments }\end{array}$ \\
\hline \multirow{6}{*}{ Social rehabilitation } & $\begin{array}{l}\text { Social and communicative } \\
\text { adaptation }\end{array}$ & $\begin{array}{l}\text { Changing the nature and circle of communication, activities in } \\
\text { small groups, changing social role }\end{array}$ \\
\hline & Social-household rehabilitation & $\begin{array}{l}\text { Activities aimed at self-sufficiency, self-care and organization } \\
\text { of everyday life in the conditions of a tourist trip. }\end{array}$ \\
\hline & $\begin{array}{l}\text { Social and environmental } \\
\text { rehabilitation }\end{array}$ & $\begin{array}{l}\text { Mastering the technology of functioning in different } \\
\text { environments }\end{array}$ \\
\hline & Socio-pedagogical rehabilitation & Mastering of new knowledge, skills and abilities \\
\hline & Social and cultural rehabilitation & $\begin{array}{l}\text { Excursions, songs, conversations, exhibitions, photo contests, } \\
\text { etc. }\end{array}$ \\
\hline & Social-psychological rehabilitation & $\begin{array}{l}\text { Social activization in the process of holding tourist events, } \\
\text { observing the successes of other people with disabilities, the } \\
\text { transformation of the worldview }\end{array}$ \\
\hline
\end{tabular}

provision of professional health-rehabilitation services.

Considering the problems of inclusive tourism, we can state its exceptional importance for the social and physical rehabilitation of people with disabilities. The peculiarity of tourism, as a means of recreation and getting knowledge of the surrounding world, is its wide coverage of almost all types of social and physical rehabilitation. It can be presented in the form of tation services, the provision of which will involve spatial-geographical aspects, rehabilitation-social, psychological and adaptive form of assistance, taking into account spatial-geographical resources and capabilities of the material and technical base for the rehabilitation of Ukrainian means of tourist services.

Therefore, the issue of comprehensive assistance to rehabilitators has become quite natural, through the development of a substantially new conceptual mod- 


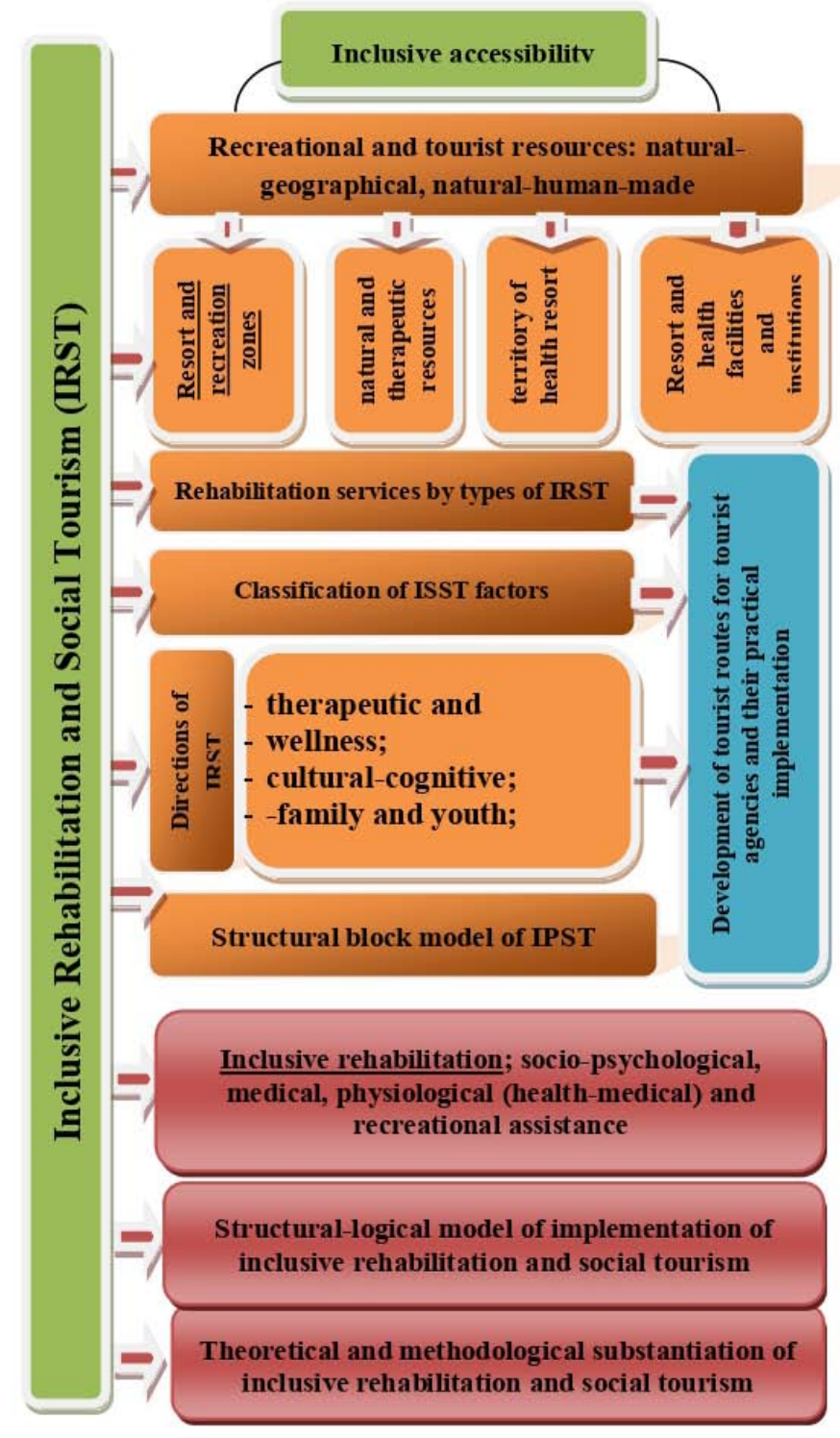

Fig.3. Block diagram of the development and implementation of inclusive rehabilitation and social tourism

el of rehabilitation for people of different inclusive groups and nosologies. Against the background of such a need, previous research, definitions and concepts of the adaptability of people with inclusion were analyzed, followed by the justification of its conceptual model (Fig. 3).

Conclusion. The idea of the development of inclusive rehabilitation and social tourism arose as a result of a number of events in recent years and changes in Ukrainian society: the increase in the number of people with disabilities due to hostilities in eastern Ukraine, expansion of the range of diseases and disabilities due to a decline in the living standards by Ukrainian expenditure indicators), lack of a balanced diet, bad habits, deterioration in the quality of drinking water and environmental instability. All this led to the destabilization of the quality of life of ordinary Ukrainian.
A number of objective and subjective factors characterizing the realities of Ukrainian life have led to the formation of a category of citizens with various inclusions and actual problems of their social inclusion and adaptation. The most effective mechanism for achieving this goal is the development of inclusive social and rehabilitation tourism, which has its own characteristics and, above all, these features relate to the formation of an "environment friendly to people with inclusive needs". Such an environment has local territorial forms and is formed on the basis of the concentration of recreational and tourist resources (balneological, natural recreational, historical and cultural), the operation of specialized rehabilitation institutions and auxiliary infrastructure facilities (social, transport).

The development of these areas is preceded by the availability of natural and recreational resources 
in the form of resort and treatment zones located on health-improving lands which have natural healing resources and objects of the natural, historical and cultural environment that can be used to organize recreational activities - recreation, treatment, tourism , taking into account the services of psychologists and psychotherapists and which could meet the need for the provision of professional recreational services.

Accordingly, the formation of an inclusive environment due to diferent researches, in the first place, in the geographical sciences, recreational geography and geography of tourism, geography of services, population and settlement geography, medical geography, etc., which together form an interdisciplinary direction of research that can be described as rehabilitation geography (by target).

At the moment, inclusive rehabilitation and social assistance is one of the least occupied niches of the Ukrainian tourist market. Therefore, the process of comprehensively studying the causes and factors of the increasing number of people who belong to inclusive groups is relevant, and justifying the theoretical and methodological framework with new approaches, methods and techniques of work in the tourism sector is appropriate.

\section{References}

Bielousova N.V. 2017. Inklyuzyvnyy turyzm» abo «podorozhi bez bar'yeriv» u suchasnomu suspil'stvi. Ukrayiny: heohrafichnyy analiz ta poshuk shlyakhiv vyrishennya [«Inclusive tourism» or «travel without barriers» in modern society] Ukraine: geographical analysis and search for solutions to materials VII International Scientific Conference, m. Kherson, 5-6 October 2017 / [edited by I.Pylypenko By D. Malchykovoyi]. - Kherson: Publishing House "Helvetica", 33-35. (in Ukrainian)

Bielousova N.V. 2018. Teoretychni aspekty rozvytku inklyuzyvnoho reabilitatsiyno-sotsial'noho turyzmu v Ukrayini. [Theoretical aspects of the development of inclusive rehabilitation and social tourism in Ukraine]. Scientific journal "Scientific notes of Sumy State Pedagogical University. Geographic Sciences ». - Sumy: Sumy MPU named after A.S.Makarenko, 9, 205-213 (in Ukrainian)

Bogdanov S. 2002. Sotsial'nyy zakhyst invalidiv. Ukrayins'kyy ta pol's'kyy dosvid [Social protection of the disabled. Ukrainian and Polish Experience] rep. edit O. Paliy - Kyiv: Fundamentals, 93 (in Ukrainian)

Bozhuk T.I. 2009. Kryteriyi otsinky kurortiv dlya tsiley porivnyal'noho analizu [Criteria for assessing resorts for the purposes of comparative analysis]
The practice of modern tourism: social and economic efficiency: mother. IV International sci. pract. Conf., October 14, 2008, Kyiv. - K .: KUTEP,.164-167 (in Ukrainian)

Bozhuk T.I. 2011. Rekreatsiyno-turystychna destynatsiya dlya potreb likuvannya ta ozdorovlennya (na prykladi kurortiv L'vivshchyny) [Recreation and tourist destination for treatment and rehabilitation needs (on the example of Lviv resorts)] Scientific Herald of Chernivtsi University. - Issue 5887588: Geography. 172-179 (in Ukrainian)

Bozhuk T.I. 2009. Kontseptsiya formuvannya rehional'noyi turystychno-informatsiynoyi systemy [Concept of the formation of the regional tourist information system] Dniester Canyon - a unique area of tourism: mother. International sci. pract. conf. (M. Ternopil, 16-18 May., 2009) / Ternopil National Pedagogical University V.Hnatyuka. - Ternopil: Textbooks and manuals, 31-32. (in Ukrainian)

Zakon Ukrayiny «Pro kurorty» [Law of Ukraine "On Resorts"] (No. 2026-III dated October 5, 2000): Retrieved from: http://www.kmu.gov.ua. (in Ukrainian)

Zvit Minsotspolityky za 2017. Derzhavna sluzhba statystyky Ukrayiny [Minsotspolitiki report for 2017. State Statistics Service of Ukraine]. - 2018. Retrieved from : www.ukrstat.gov.ua. (in Ukrainian)

Zminy do st.26 Zakonu Ukrayiny «Pro reabilitatsiyu invalidiv v Ukrayini». Ukhvala Verkhovnoyu Radoyu Ukrayiny (August, 2018 roku). [Changes to Article 26 of the Law of Ukraine «On the Rehabilitation of Disabled Persons in Ukraine»]. Verdict of the Verkhovna Rada of Ukraine (31.08.2018).

Retrieved from: https://zakon.rada.gov.ua/laws/ show/2961-15 (in Ukrainian)

Lukashevich M.P., Moshak S.M., Shandor F.F. 2015. Sotsiolohiya turyzmu [Sociology of Tourism]: Textbook. - K.: Knowledge. 303. - (Higher education of the XXI century) (in Ukrainian)

Malskaya M.P., Khudo V. V. 2007. Turystychnyy biznes [Tourist Business]: Theory and Practice: Teach. manual. - Kyiv: ZUL, - 424 p. (in Ukrainian)

Natsional'na prohrama profesiynoyi reabilitatsiyi ta zaynyatosti osib z obmezhenymy fizychnymy mozhlyvostyamy na 2006-2010 roky [National program of professional rehabilitation and employment of persons with disabilities for 2006-2010]. - Laws of Ukraine. - Volume 1. - K.: JSC «Book», 1996, 291-300. (in Ukrainian)

Postanova Kabinetu Ministriv vid 27 hrudnya 2017 r. № 1057 «Pro zatverdzhennya Poryadku provedennya psykholohichnoyi reabilitatsiyi uchasnykiv antyterorystychnoyi operatsiyi ta postrazhdalykh uchasnykiv Revolyutsiyi Hidnosti».[On December 27, 2017, the Cabinet of Ministers of Ukraine dated December 27, 2017, No. 1057 «On Approval of the Procedure for the Psychological Rehabilitation of the Participants of the Anti- 
terrorist Operation and the Victims of the Victory Revolution»] Retrieved from: https://zakon. rada.gov.ua/laws/show/1057-2017-\%D0\%BF (in Ukrainian)

Proekt «Bezbaryerna Ukrayina» [Project «Barefooted Ukraine»], NAIU. 2016. Retrieved from: http:// netb aryerov.org.ua/dostup/methodika (in Ukrainian)

Rehional'na dovidka pro stan vykonannya Prohramy dostupnosti $v$ Ukrayini [Regional information on the state of implementation of the Accessibility Program in Ukraine] - Retrieved from: http:// netbaryerov.org.ua/dostup/metodika/51-material/ dodatki/1310-2013-04-11-08-46 -56 (in Ukrainian)

Statystyka ta analiz malomobil'nykh verstv naselennya [Statistics and analysis of the low-mass population] [Electronic resource] / Malinka V. / NGO "Human Rights". -2018. - Retrieved from: http://prava-lyudyny.org/u-programah-partij-navybory-u-kyyevi- majzhe-ne-vrahovani-interesymalomobilnyh-grup / (in Ukrainian)

Ustimenko LM, Afanasyeva I.V. 2005. Istoriya turyzmu [History of Tourism]: Teach. manual. K .: AlterPres,. 320 (in Ukrainian)

Deno, E.N. 1970. Special Education as Developmental Capital [Special Education as Developmental Capital]. E.N Deno. Exceptional Children. 37. 229-237

Wang H. L. 2009. Should All Students with Special Educational Needs (SEN) be Included in Mainstream Education Provision? : a critical analysis. International Education Studies. 2 (4). 154-160. 